https://journal.uwgm.ac.id/index.php/abdimasmahakam

E-ISSN: 2549-5755

Januari 2020, Vol. 4 No. 01

\begin{tabular}{l|l|l|}
\hline Received: Agustus 2019 & Accepted: November 2019 & Published: Januari 2020 \\
\hline
\end{tabular}

Article DOI: http://dx.doi.org/ 10.24903/jam.v4i1.511

\title{
Pemulihan Ekonomi Rumah Tangga Perkebunan Sawit Rakyat Terkena Dampak Kebakaran Lahan dan Hutan
}

\author{
Ardi Novra \\ ardinovra@unja.ac.id \\ Universitas Jambi \\ Suparjo Suparjo \\ suparjo@unja.ac.id \\ Universitas Jambi \\ Abdul Latief \\ Abdullatief_unja@yahoo.com \\ Universitas Jambi \\ Suhessy Syarif \\ suhessysyarif@yahoo.co.id \\ Universitas Jambi
}

\begin{abstract}
Abstrak
Kegiatan PPM bertujuan untuk pemulihan ekonomi rumah tangga sawit terkena dampak karhutla tahun 2015. Program PPM mampu memantik partisipasi pihak dunia usaha melalui program CSR yaitu PT. WKS berkontribusi dalam perbaikan jalan produksi dan berkomeitmen menyerap seluruh produk kompos, dan Bank Indonesia berkomitmen memberikan bantuan modal perluasan rumah kompos dan perbaikan kandang guna akselerasi target produksi. S esuai perjanjian kerjasama antara PMJ dan PT. WKS pada saat lounching perdana yaitu 200 ton/bulan dari capaian produksi 50-60 ton/bulan saat ini. Pemasok utama bahan baku limbah usaha pupuk kompos adalah rumah tangga peternak sapi setempat dan desa sekitar. Berdasarkan hasil kegiatan maka dapat disimpulkan bahwa program PPM mampu membangkitkan motivasi pemanfaatan limbah insitu, menjadi sumber pendapatan alternatif guna pemulihan ekonomi pasca karlahut, pemicu partisipasi pihak lain serta merupakan langkah awal menuju kesiapan rumah tangga menghadapi program peremajaan sawit.
\end{abstract}

Kata Kunci: pemulihan; ekonomi; limbah; kompos; dan sawit. 


\section{(A) ABDIMAS}

https://journal.uwgm.ac.id/index.php/abdimasmahakam

E-ISSN: 2549-5755

Januari 2020, Vol. 4 No. 01

\section{Pendahuluan}

Kebakaran hutan dan lahan (karhutla) di Sumatera dan Kalimantan seperti semacam ritual tahunan kembali terulang. mayoritas terjadi akibat ulah segelintir orang dan perusahaan. Praktek-praktek membuka lahan baru secara murah ini telah membuat banyak warga di negara ini serta negara tetangga sengsara. Karhutla tahun 2015 di Provinsi Jambi menjadi momok yang meresahkan warga karena lebih dua bulan diselimuti kabut asap. Pantauan BLHD Provinsi Jambi melalui AQMS, Indeks Standar Pencemaran Udara (ISPU) berada diangka 730 atau kategori sangat berbahaya dan ini pertama kali terjadi sejak karhutla tahun 1997. Dampak lain adalah lebih satu bulan aktifitas belajar mengajar dihentikan, jarak pandang terendah mencapai 200-meter yang menyebabkan lumpuhnya aktifitas penerbangan selama lebih dari satu bulan, hutan Pematang Damar seluas 240 Ha tersisa hanya sekitar 50 70 Ha menyebabkan 80 jenis anggrek musnah (tak ditemukan lagi), luas lahan gambut terbakar mencapai 19.528 Ha.

Paparan kabut asap dan kemarau panjang mengakibatkan produktivitas tanaman duku menurun drastis dari normalnya 120 batang bisa panen 20-ton namun pasca karhutla menurun drastis menjadi 4 ton. Hal yang sama terjadi pada tanaman durian yang seharusnya bulan Februari 2016 sudah memasuki musim durian, namun faktanya banyak pohon yang tak berbuah. Karhutla bertepatan dengan awal munculnya putik buah durian membuat putik berguguran sehingga pohon tak berbuah dan jika masih ada biasanya 10 buah/batang dan menurut warga ini persis seperti yang terjadi di tahun 1997 silam. Hal yang sama terjadi pada tanaman perkebunan berupa turun drastisnya produktivitas sawit akibat kabut asap karena terganggunya proses fotosintesa (Erwinsyah, 2014). Gangguan fotosintesis nutrisi menyebabkan klorofil daun memasak makanan tidak maksimal karena tercemarnya karbondioksida yang dibutuhkan tanaman (Biocond, 2016).

Penanganan pasca karhutla adalah semua usaha, tindakan atau kegiatan yang meliputi inventarisasi, monitoring dan evaluasi serta koordinasi dalam rangka menangani suatu areal setelah terbakar. Salah satu bentuk penanganan adalah rehabilitasi yaitu seluruh kegiatan dalam rangka merehabilitasi kawasan bekas dan terdampak akibat kebakaran dengan mempertimbangkan rekomendasi dan/atau masukan berdasarkan data dan informasi yang diperoleh dari hasil identifikasi. Pemulihan produktivitas tanaman kelapa sawit secara alami menurut Erwinsyah (2014) membutuhkan waktu cukup lama bisa 2 - 3 tahun. Pemulihan menggunakan bahan kimia untuk memacu pertumbuhan bunga disamping mahal juga belum tentu efektif sehingga tidak direkomendasikan. Alternatif yang dapat dilakukan adalah melalui penguatan ekonomi rumah tangga petani sawit dengan memaksimalkan pemanfaatan sumberdaya sekitar (insitu) seperti limbah tanaman pertanian dan peternakan.

Desa Dataran Kempas merupakan desa dengan mayoritas rumah tangga adalah petani perkebunan sawit rakyat dengan luas areal sekitar 382 Ha dengan masa tanam tahun 1995/1996 sehingga 1 - 3 tahun lagi memasuki masa peremajaan (umur tanaman nonproduktif 25 tahun). Pasca kejadian kebakaran lahan dan hutan besar pada tahun 2015 perekonomian desa mengalami kemunduran drastis akibat anjloknya produktsi tanaman sawit masyarakat. Pemulihan kembali produktivitas tanaman sawit pasca karhutla besar 2015 diperkirakan berlangsung 2 - 3 tahun, sedangkan harga jual TBS pada saat yang hampir bersamaan mencapai harga terendah yaitu Rp. 600/kg. Berdasarkan analisis situasi maka dilakukan kegiatan PPM dengan tujuan mendorong pemanfaatan sumberdaya lokal oleh kelompok masyarakat terkena dampak karlahut 2015 dalam kerangka pemulihan ekonomi 


\section{(A) ABDIMAS}

https://journal.uwgm.ac.id/index.php/abdimasmahakam

E-ISSN: 2549-5755

Januari 2020, Vol. 4 No. 01

rumah tangga sekaligus mendorong kemandirian dalam menghadapi program peremajaan sawit rakyat.

\section{Metode}

Kegiatan dilaksanakan di Desa Dataran Kempas Kecamatan Tebing Tinggi Kabupaten Tanjung Jabung Barat selama 6 (enam) bulan dengan mitra sasaran adalah Poktan Mekar Jaya yang merupakan pelaku integrasi sawit sapi. Metode pemberdayaan masyarakat guna pemulihan ekonomi rumah tangga terkena dampak kabakaran lahan dan hutan tahun 2015 menggunakan pendekatan partisipatif (Participatory Rural Appraisal/PRA) yaitu suatu metode pendekatan dalam proses pemberdayaan dan peningkatan partisipasi masyarakat yang ditekankan pada keterlibatan masyarakat dalam keseluruhan kegiatan pembangunan (Firmansyah, 2013). PRA merupakan salah satu bentuk community-based method yang berada dalam konteks collaborative decision making dimana koleksi dan analisis data dilakukan oleh masyarakat lokal dan pihak luar lebih berperan sebagai fasilitator dibanding pengontrol kebijakan (Syahyuti, 2008). Pada sisi lain individu secara alami cenderung memilih aksi bersama ketika ada kesamaan dalam hal tujuan yang ingin dicapai dan ketika merasa adanya ketidakpastian dan resiko yang dihadapi jika bergerak sendirian (Syamsuddin et al., 2007). Partisipasi anggota fokus pada pengadaan bahan baku unit usaha pengolahan limbah ternak sapi potong dan pemanfaatan produk olahan pupuk organik untuk pemulihan lahan dan tanaman terkena dampak paparan asap kebakaran lahan dan hutan. Jenis teknologi Terapan terdiri dari a) teknologi proses produksi Trychokompos Insitu, dan b) teknologi proses produksi Biourine A Plus dengan tahapan pelaksanaan kegiatan (Gambar 1).

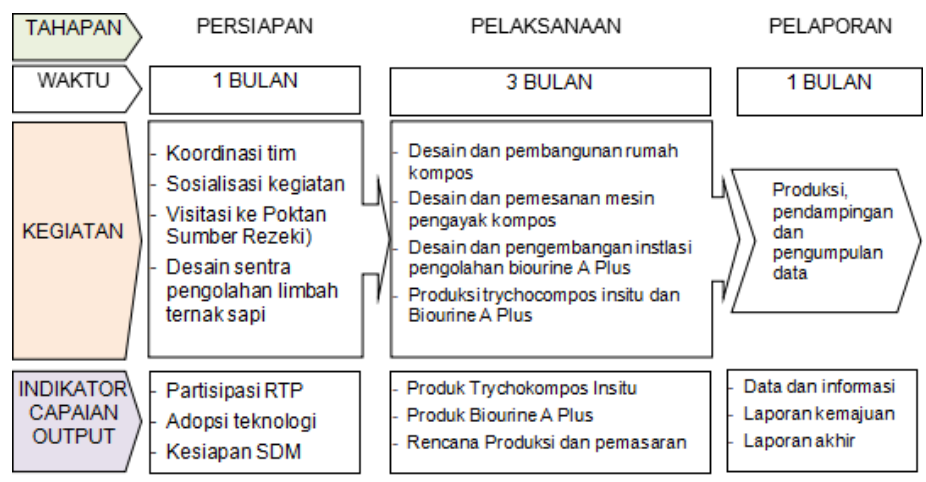

Gambar 1. Tahapan Pelaksanaan dan Indikator Capaian

Secara umum kegiatan PPM terdiri dari beberapa tahapan pelaksanaan seperti disajikan pada rangkaian Gambar 2. 


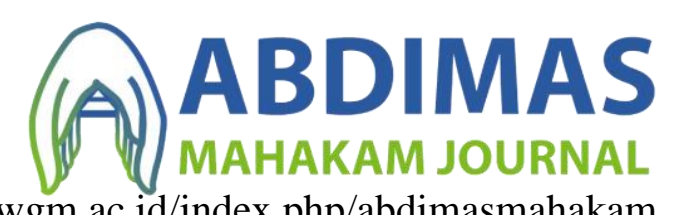

https://journal.uwgm.ac.id/index.php/abdimasmahakam

E-ISSN: 2549-5755

Januari 2020, Vol. 4 No. 01

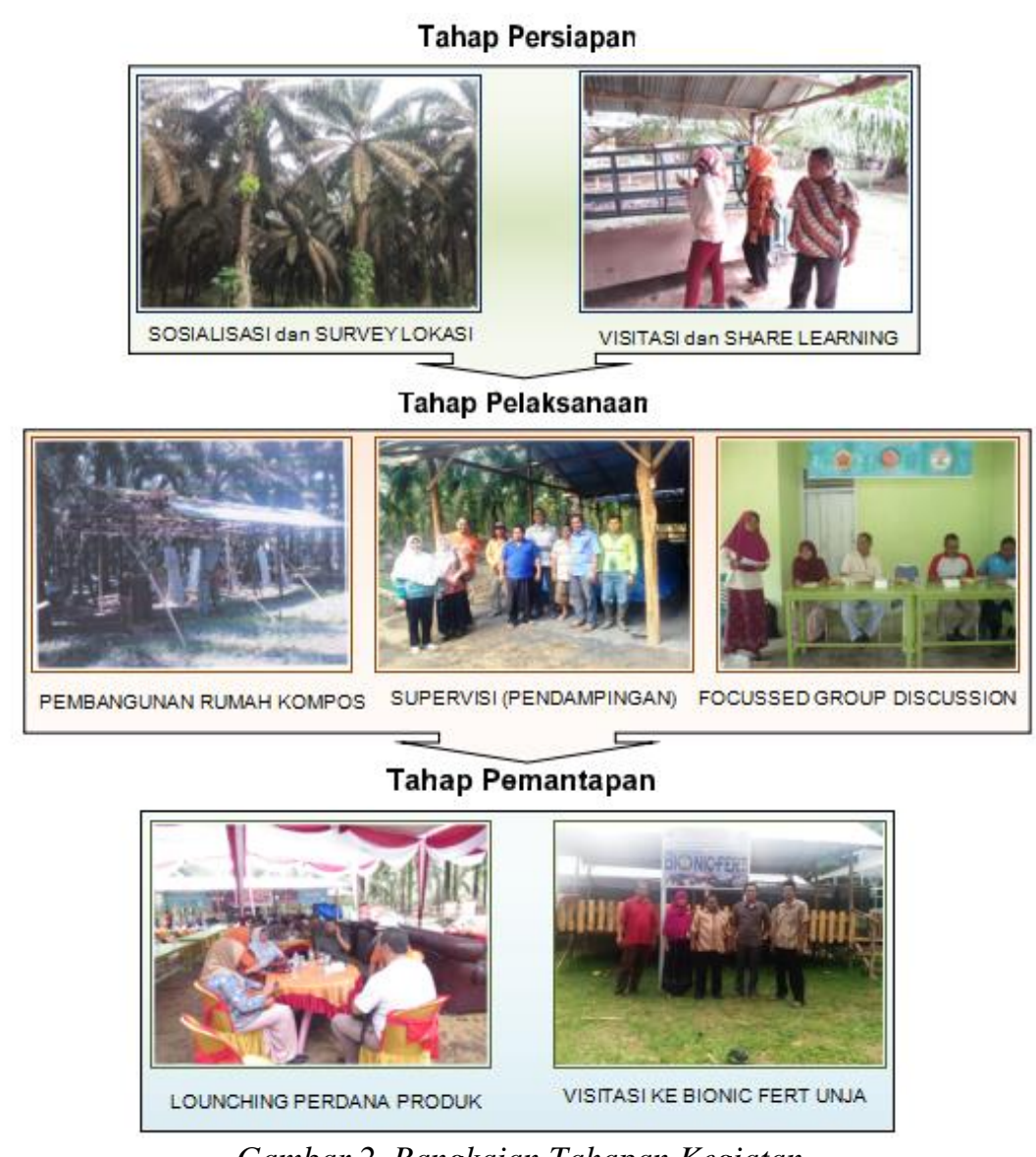

Gambar 2. Rangkaian Tahapan Kegiatan

\section{Hasil dan Pembahasan}

Proses produksi trychokompos dilakukan pada rumah kompos yang sudah dibangun dengan kapasitas produksi 50 ton/bulan sesuai dengan pesanan PT. WKS sebagai pembeli utama produk biokompos. Rumah kompos dibagi atas 6 bagian yang terdiri dari 1 bagian untuk pasca komposing (pengayakan dan pengemasan) dan 5 bagian untuk proses komposing dengan kapasitas produksi 5 - 10-ton untuk setiap periode pengomposan. Selama proses komposing bahan baku limbah padat kandang yang sudah dicampur dengan berbagai bahan tambahan lainnya seperti tandan buah kosong sawit, dedak padi dan lainnya ditutup dengan terpal warna biru selama \pm 20 hari. Proses produksi ini masih berbeda dengan teknologi introduksi yang ditawarkan karena beberapa hal sebagai berikut a) sebelum tim pelaksana PPM Universitas Jambi berpartisipasi sudah ada kegiatan pelatihan teknologi pengolahan biokompos yang dilaksanakan oleh PT. WKS dan telah diuji coba oleh kelompok tani Mekar Jaya pada rumah kompos yang dibangun, b) hasil uji coba komposing tersebut telah dilakukan uji laboratorium dengan hasil kandungan unsur hara sesuai dengan standar kompos yang ditetapkan PT. WKS. Pada sisi lain, pesanan sesuai kontrak dengan perusahaan harus segera disupplai sehingga perubahan proses produksi seperti yang telah diintroduksikan untuk sementara ditunda terlebih dahulu, c) proses produksi menggunakan pendekatan yang ditawarkan membutuhkan trychoderma sebagai mikroba yang akan membantu proses dekomposisi, sementara supplainya masih harus didatangkan dari produsen khusus yang 


\section{(A) ABDIMAS}

https://journal.uwgm.ac.id/index.php/abdimasmahakam

E-ISSN: 2549-5755

Januari 2020, Vol. 4 No. 01

berada jauh di Kota Jambi. Besarnya target volume produksi pupuk kompos menyebabkan kebutuhan trychoderma juga cukup besar sehingga pasokan akan diusahakan secara mandiri dengan mengembangkan kerjasama antara laboratorium PT. WKS dan Poktan Mekar Jaya untuk produksi trychoderma dibawah supervisi LPPM Universitas Jambi, dan d) PT. WKS sebagai pembeli utama pada dasarnya membutuhkan pupuk kompos dalam bentuk trychokompos-insitu sebagaimana yang ditawarkan tim pelaksana PPM Universitas Jambi.

Sebagai tindak lanjut kerjasama antar pihak maka telah dilaksanakan kegiatan FGD (Focussed Group Discussion) oleh Tim Peneliti MP3EI UGM yang bekerja sama dengan Pusat Penelitian CSR LPPM Universitas Jambi pada tanggal 29 September 2016 di Aula Kantor Desa Dataran Kempas. Pada kegiatan FGD ini disepakati kontribusi masing-masing pihak dalam peningkatan kapasitas produksi dan kegiatan alternatif ekonomi alternatif lainnya yang akan dikembangkan pada Desa Dataran Kempas khususnya pada kawasan sentra produksi Poktan Mekar Jaya. Kegiatan FGD yang diikuti oleh berbagai komponen masyarakat Desa Dataran Kempas dipandu oleh Tim Peneliti MP3EI Universitas Gadjah Mada dengan Narasumber dari PT. WKS dan Puslit CSR Universitas Jambi. Hasil kesepakatan dalam FGD antara lain bahwa proses produksi biokompos yang dilakukan selama ini bersifat sementara dan akan dilakukan perubahan secara perlahan setelah dilakukan proses produksi trychoderma secara mandiri. PT. WKS berkerja sama dengan LPPM Unja akan segera melakukan kegiatan pelatihan dan pendampingan teknologi proses dalam pengembangan trychoderma, dan mengkaji pemanfaatan laboratorium perusahaan untuk produksi bibit indukan trychoderma sehingga pengembangbiakan secara luas dapat dilakukan mandiri oleh masyarakat Desa Dataran Kempas.

Luas areal lokasi sentra produksi unit bisnis yang dicadangkan kelompok Mekar Jaya mencapai lebih dari 2 Ha terletak pada lokasi desa yang mudah diakses. Lahan tersebut disamping dicadangkan untuk perluasan skala usaha juga diharapkan menjadi lokasi unit-unit usaha kelompok lainnya yang berbasis pada teknologi ramah lingkungan. Pada tahap awal diarahkan untuk pengembangan demplot-demplot percontohan terutama berkaitan dengan pengembangan unit usaha produktif sebagai sumber pendapatan alternatif. Hal ini dilakukan guna mempersiapakan rumah tangga anggota kelompok dalam menghadapi program peremajaan sawit atau yang lebih dikenal dengan program replanting sawit. Beberapa persyaratan sebagai areal peragaan teknologi bagi pengembangan usaha ekonomi produktif (UEP) berbasis pada pemanfaatan sumberdaya alam dan limbah in-situ. Langkah pertama dalam penataan kawasan dan paket teknologi yang akan dikembangkan, maka Kepala Desa dan beberapa orang pengurus Poktan dan LKMA melakukan visitasi ke kawasan unit bisnis Bionic-Fert di areal Fapet Farm Fakultas Peternakan Universitas Jambi. Unit bisnis ini merupakan kerjasama antara Fakultas Peternakan Universitas Jambi dan PUI-PT Konsorsium Riset Teknologi Reklamasi Lahan (KRT-Rekla) Universitas Jambi. Visitasi ini dilaksanakan setelah Poktan Mekar Jaya menandatangani bantuan permodalan dari Bank Indonesia (BI) Jambi untuk pengembangan kapasitas produksi biokompos. Dana bantuan modal pengembangan usaha yang berhasil diperoleh Poktan Mekar Jaya baik secara langsung maupun tidak langsung diakui sebagai dampak dari kerjasama antar pihak dalam pengembangan unit usaha pengolahan limbah kandang ternak sapi kelompok. Kehadiran Bank Indonesia dalam kegiatan lounching pemasaran perdana produksi biokompos menjadi pemicu keinginan managemen CSR mereka untuk ikut berpartisipasi dalam pembinaan dan pengembangan usaha ekonomi produktif bagi masyarakat. 
https://journal.uwgm.ac.id/index.php/abdimasmahakam

E-ISSN: 2549-5755

Januari 2020, Vol. 4 No. 01

Hasil diskusi dengan pengelola selama visitasi menimbulkan sebuah gagasan cemerlang untuk secara bersama-sama dengan berbagai pihak akan menjadikan kawasan sentra produksi Poktan Mekar Jaya menjadi kawasan wisata pendidikan (edu-wisata) yang akan menampilkan berbagai bentuk pemanfaatan dan aplikasi teknologi tept guna bagi pemberdayaan ekonomi rumah tangga menghadapi program replanting sawit. Kawasan ini diharapkan menjadi monumen dan saksi sejarah bagaimana masyarakat melalui program Gema Nusantara Pengintegrasian Program Desa Dataran Kempas secara mandiri dan berkelanjutan menghadapi program replanting kelapa sawit. Langkah awal menuju kearah pengembangan kawasan edu-wisata dilakukan dengan rencana memasang spanduk Gerbang Selamat Datang Desa dan Kawasan Sentra Produksi.

\section{Simpulan dan rekomendasi}

Berdasarkan uraian perjalanan pelaksanaan PPM maka dapat disimpulkan bahwa rogram PPM berhasil meningkatkan motivasi rumah tangga pelaku integrasi sapi sawit untuk pengembangan unit usaha kelompok berbasis limbah insitu (limbah kandang dan limbah tanaman), dan dengan anggaran terbatas mampu menjadi faktor pemicu partisipasi pihakpihak eksternal terutama dunia usaha dan pemerintah daerah. Kebijakan untuk akselerasi perkembangan usaha poktan Mekar Jaya Desa Dataran Kempas membutuhkan keterlibatan dan jalianan kerjasama antara berbagai pihak baik dunia usaha, perguruan tinggi maupun lembaga litbang dan pemerintah daerah. 


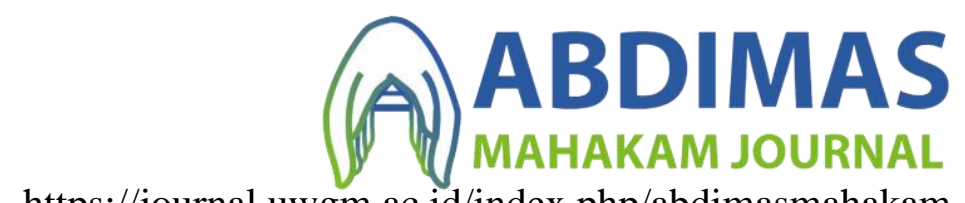

https://journal.uwgm.ac.id/index.php/abdimasmahakam

E-ISSN: 2549-5755

Januari 2020, Vol. 4 No. 01

\section{Daftar Pustaka}

Biocond, 2016. Meminimalkan Dampak Kabut Asap Pada Tanaman Pertanian Perkebunan, Komunitas Pemerhati Budidaya Organik dalam Bidang Pertanian, Perkebunan, Peternakan dan Perikanan Yogyakarta, http://biocondjogja. blogspot.com/2016/ Accessed August $22^{\text {th }} 2016$.

Erwinsyah, 2014. Kabut Asap Turunkan Produktivitas Kelapa Sawit, Beranda PTPN V, Medan, $\quad$ https://www.ptpn5.com/berita-352-kabut-asap-turunkan-produktivitaskelapa-sawit.html., Accessed April $1^{\text {st }} 2014$

Firmansyahm 2013. Pekerjaan Sosial: Pengertian Participatory Rural Appraisal https://kesejahteraansosial.blogspot.com/2013/02/pengertian-participatory -ruralappraisal-pra.html ,Accessed February $5^{\text {th }}$ 2013,

Novra, A., Suparjo, Endriani dan A. Meilin, 2015a. Buku Panduan Proses Produksi Biourine Aerasi Plus. Penelitian PENPRINAS MP3EI 2011-2025, LPPM Universitas Jambi, Jambi.

, 2015b. Buku Panduan Proses Produksi Trychoderma Insitu. Penelitian PENPRINAS MP3EI 2011-2025, LPPM Universitas Jambi, Jambi.

Novra, A., Adriani, Suparjo, dan Nelson, 2015. Penguatan Usaha Kelompok Peternak Pelaku Integrasi Sawit - Sapi Berbasis Limbah di Kecamatan Mestong, Laporan Hasil Kegiatan IPTEKDA-LIPI 2015, Fak. Peternakan Universitas Jambi, Jambi.

Syahyuti, 2008. 30 (Tiga Puluh) Konsep Pembangunan Pedesaan dan Pertanian, https://konseppedesaanpertanian.blogspot.com/2008/08/participatory-rural-appraisalpra.html Accessed: August 22th 2008.

Syamsuddin, Neldysavrino, Komarudin, H. and Y. Siagian. 2007. Are Community Aspirations Being Accommodated In Development Plans? A Lesson from Collective Action in Jambi. CIFOR Governance Brief No. 34. Bogor, Indonesia:. 